\title{
VIETNAMESE STUDENTS' ACCEPTANCE OF USING VIDEO CONFERENCING TOOLS IN DISTANCE LEARNING IN COVID-19 PANDEMIC
}

\author{
Xuan-An NGUYEN \\ ORCID: 0000-0002-4287-0085 \\ Vietnam National Institute of Educational Sciences \\ Hanoi, VIETNAM \\ Dr. Duc-Hoa PHO \\ ORCID: 0000-0002-1198-6181 \\ Hanoi National University of Education \\ Hanoi, VIETNAM \\ Dinh-Hai LUONG \\ ORCID: 0000-0003-0167-2645 \\ The Vietnam National Institute of Educational Sciences \\ Hanoi, VIETNAM \\ Dr. Xuan-Thuc-Anh CAO \\ ORCID: 0000-0001-6526-577X \\ English Department, Hanoi University \\ Hanoi, VIETNAM
}

Received: 26/06/2020 Accepted: 20/11/2020

\begin{abstract}
The outbreak of the COVID-19 pandemic has strongly influenced teaching and learning in Vietnam's higher education institutions. Social distancing - the health care practice of increasing the physical space between people to avoid spreading illness due to COVID-19 has required schools to employ distance learning. As such, video conferencing tools (VCTs) have been used nationwide to ensure effective responses to the requirement. Although teaching and learning with VCTs have been proven effective by many researchers, it is not clear what benefits and challenges they bring to higher education in Vietnam, especially with respect to students' acceptance to the classroom uses of technology in the time of unexpected events. This study aims to address this gap by examining external factors that affected students' acceptance of VCTs during the COVID pandemic. Data were collected online from university students between April 14, 2020 and April 23, 2020. After this period, the research group received 294 records, in which 227 were analyzed using an extended Technology Acceptance Model (TAM) and Structural Equation Modeling (SEM). The result indicated that external factors such as subject norm and computer playfulness had a significant impact on most TAM constructs. Furthermore, output quality was found to have a positive influence on students' perceived usefulness in the acceptance of VCTs in distance learning.
\end{abstract}

Keywords: Distance learning, video conferencing, students’ acceptance, TAM, COVID-19

\section{INTRODUCTION}

COVID-19, which belongs to SARS-CoV-2 family (Gorbalenya et al., 2020), broke out from Wuhan, Hubei province, China at the end of December 2019 (Kraemer et al., 2020; Sun et al., 2020; Weston and Frieman, 2020), caused World Health Organization (WHO) to disclose a public health emergency of international concern (World Health Organization, 2020). Only two months after the announcement, on 
March 11 2020, WHO officially declared COVID-19 a pandemic. Vietnam shares the border with China, but it was not until two months after the outbreak of COVID-19 in China did Vietnam have some first few cases related to Wuhan (Vietnam Ministry of Health, 2020). The Vietnamese Government publicly announced the disease on February 01, 2020 (Vietnamese Government, 2020) to halt and prevent the disease from spreading. Since then, they have been taking some firm actions such as closing down the border, putting passengers from overseas in quarantine, social distancing, putting on hold all schooling systems, and stopping unnecessary activities.

The above events have led to Vietnam's education sector's decision to work with a new motto: no schooling, but still learning, and distance learning, the access for geographically distant students (Moore et al., 2011) via the Internet and television, among others, is a contemporary solution that can digitally transform education (Online Newspaper of The Goverment Vietnam, 2020). At the higher education level, Vietnam Ministry of Education and Training (MOET) officially granted institutions the right to study at home, as long as they could maintain the quality of learning (Tran, 2020). At the same time, MOET formally requested Higher Education Institutes (HEIs) to operate distance learning as a temporary plan during COVID-19 (Vietnam Ministry of Education and Training, 2020), and the result of this training method will be officially recognized (Ha Anh, 2020). HEIs actively adapted information technology into their curriculum (Tran, 2020). Distance learning was operated in two main ways: streaming videos of recorded lessons on HEIs' official websites or fan pages, or employing VCTs like Zoom, Teams, Google Classroom, Facebook groups, etc. (Vietnam National University Media, 2020). Between the two, VCTs were more favored as a substitution for traditional face-toface classrooms, and thus, has been widely used in global education, especially during COVID-19.

The increasing popularity of information and communication technology (ICT) encourages a wide use of technologies in training, with a goal of enhancing the teaching and learning quality. Learning with VCTs is preferred as they sufficiently connect the teacher with the learner or one learner to another when they have to distance learn instead of going to their classrooms (Al-Samarraie, 2019; Mader \& Ming, 2015; Willis, 1996; Zare \& Yazdanparast, 2013). At the same time, more researchers are getting interested in technology acceptance in education (Al-Emran et al., 2018; Imtiaz \& Maarop, 2014; Teo et al., 2011) and the essential incorporation of technology in such context (Granic \& Marangunic, 2019; Scherer et al., 2019). Students' acceptance is a well-researched concept in distance learning, which can certify the acceptance of technology uses in supporting learning (Al-Maroof \& Al-Emran, 2018; El-Gayar et al., 2011; Nassuora, 2013). The use of technology may positively influence the successful implementation of students (Martins \& Kellermanns, 2004).

The unexpected impacts of COVID-19 strongly required the adoption of VCTs to teach and learn. As a result, there is a need to study the use of VCTs, as well as their pros and cons, especially in relation to students' acceptance of the tools. According to our limited experience, there are a few studies on VCTs, but they do not focus on the same subject as ours. To fill this research gap, this study aims at (1) empirically examining the TAM constructs concerning Vietnamese students' acceptance of VCTs in distance learning during the social distancing period caused by the COVID-19, and (2) through the literature review, determining the external factors which influenced Vietnamese students' acceptance of VCTs in distance learning during the social distancing period caused by the COVID-19.

Expectedly through this research, other researchers' competence in VCTs will be enhanced. At the same time, by providing a better insight into the social, and technical factors that facilitate VCTs, it is hoped that the frequency and effectiveness of VCTs adoption in distance learning will be improved. Furthermore, the understanding of these factors may help managers, instructors, and service providers determine the advantages and disadvantages of VCTs in distance learning, and in turn, have better policies for technology infrastructures and assistance services to facilitate higher level achievement of technology acceptance and students' performances.

This study identifies five periods of disease outbreak in Vietnam, namely (i) pre-January 23, (ii) between January 23 and February 26 when the first batch of sixteen patients were tested and treated till their discharge, (iii) between February 27 and March 5 when there was no new case, and (iv) post-March 6 when the 17th patient was detected, leading a new wave of infections from incoming tourists and returning travelers into Vietnam, causing the country to implement the social distancing nationwide. This study focused on the 2nd phase to 4th phase where students were studied at home by distance learning through VCTs. 


\section{LITERATURE REVIEW}

\section{Learning in COVID-19 Context}

The outbreak of COVID-19 in the beginning of 2020 has resulted in a total or semi lockdown in many countries all over the world. Education is one among the sectors which have received heavy impacts from the pandemic. A survey carried out by United Nations Educational Scientific and Cultural Organization (UNESCO) Institute for Statistics Data (UNESCO, 2020a) reports 1,198,530,172 learners affected, which accounts for $70 \%$ of the student population worldwide. Educational institutions must cease their usual faceto-face lessons and find a substitution to ensure the quality of teaching and learning. Schools and universities have resorted to distance learning, and they have a wide variety of platforms to choose from. UNESCO and The World Bank offer systems specially built for distance learning, many of which are telephone or computer based with synchronous communication (UNESCO, 2020b; World Bank, 2020). With distance learning technology, learners are able to download online lectures, interact with one another on the Internet, and take distance exams, which tremendously changes the face of education (Jones, 2020). This solution can be applied into various contexts but with more personalization (Chesbrough, 2020).

In such a crisis, the use of video calling as a communication tool in work and study widely spreads and rockets in popularity. One example of this tendency is an increase in the number of Zoom user who uses it for online meetings from 10 million before the outbreak of COVID-19 to 300 million by April 2020, about 4 months after it started (Nash, 2020). This issue, however, caused a phenomenon called "Zoom fatigue" as users have to work on the platform too frequently (Wiederhold, 2020). Although this term is rooted in social media and has just recently been used, many have been searching for it on Google, proving its intensity and prevailing power (Fosslien \& Duffy, 2020). The symptom of the so-called "Zoom fatigue" are weariness, exhaustion, or restlessness after continuous use of tools whose basis are CMC platforms with the support from AVTs and VCTs (J. Lee, 2020; Nadler, 2020; Oerther \& Shattell, 2020). As universities are interrupted, students have to switch to distance learning through VCTs, leading to a higher amount of time spent in front of smart devices' screens. This issue may lead to the widespread of "Zoom fatigue" among students and affect their motivation, as well as the quality of learning.

\section{Distance Learning}

About one century ago, learning and teaching were compulsory a face-to-face experience. It would have been impossible to imagine a classroom not bounded by walls, with all learners and teachers present. However, distance education came as a new concept among learners and teachers. In fact, it is far from a priority of the highly developed 21 st century, but has existed since the time of postal service. A description of Lawson et al., (2010) takes us back to the time when learning materials were sent via mails to distance learners who could not present in the classroom. Learners could then send back their work to be assessed, maintaining the communication between them and teachers. It is flexible and cost-effective, especially with the assistance of advanced technology ( Lawson et al., 2010; Kerka, 1996; Salmon, 2000). Other values of distance learning include different experiences of teaching and learning, and student's autonomy (Mader \& Ming, 2015).

When technologies are adopted into the distance learning process, the learner does not wait until they receive their post to start learning, but can do it almost immediately after the teacher delivers the lessons. Lawson and Mader name the advantages of both synchronous and asynchronous communication when such tools as emails, chat boxes, or video conferences are engaged. Most notably, when distance learners reach each other or the teacher synchronously, they receive immediate responses (Offir \& Lev, 1999). Since the Internet has reached many corners of the world and its users are used to video calling, distance learning is now more feasible than ever.

With the medical urgency caused by COVID-19, world education is facing a challenge related to a shift in teaching and learning because learners cannot physically present in the classroom (A. Bozkurt et al., 2020). Distance learning and teaching, therefore, emerge as a crucial solution if the fluency of education and training in HEIs are to be ensured. Although there are various practices of teaching and learning across countries during the COVID-19 pandemic, for instance, distance learning or homeschooling, the terms used to address the practices have not been able to depict the problem as well as "emergency remote education" (ERE) (A. Bozkurt 
et al., 2020; Hodges et al., 2020). According to A. Bozkurt et al (2020), ERE can be counted as one division of distance education, along with the previously mentioned forms. However, distance education and ERE have certain distinctions. While the former is planned and draws the attention of users to the theory and practice of a field, the latter focuses on the physical distance and puts its stress on the endurance and resilience with what is accessible both online and/or offline (Bozkurt \& Sharma, 2020). ERE should be the provisional answer to an urgent situation (Golden, 2020). To improve its effectiveness, it should be taken into consideration in diverse fields such as psychology, sociology, or therapy (Bozkurt \& Sharma, 2020).

\section{Video Conferencing as Tools Distance Learning}

Video-conferencing is defined as a means of communication between people from geographically different places, which can be in the form of audio calls on the telephone, or video calls on the computer (Cole et al., 2009; Lawson et al., 2010; Mader \& Ming, 2015). With the help of video-conferencing tools, most significantly the computer, users are able to see and hear one another at the same time. A video-conference may include two devices (point-to-point), or more than two (multi-point). Lawson also points out that the differences between desktop-conferencing and studio-based-conferencing lie in their focus. While the former often involves individual uses, the latter is for more formal meetings. The cost and quality of them are not the same for that matter.

Moody and Wieland (2010) summarize video-conferencing origin, which is related to the need to communicate in different ways with the aid of technology. They trace it back to Bell Telephone Laboratory's introduction of two television screens connected to the telephones in the late 1920s. Four decades after this event, video-conferencing tools were exhibited at New York's world fair as an innovation that could take over the traditional telephone's role. According to them, it was not until the end of the 20th century that videoconferencing became widespread. The Internet Protocol and other inventions such as the PC-based system, or the video with colors, gave it a powerful push as it provided more cost-efficient assets. At the beginning of the 21st century, a wide Internet access brought video-conferencing to a wide variety of users, from individuals to companies and institutions. Moody and Wieland (2010) predict that video-conferencing does not stop here, but will develop even further in the future.

A study by Al-Samarraie (2019) divides video-conferencing into three types as following:

- Desktop video-conferencing (DVC) allows participants to use more than one channel to learn. This method can connect one person with another, one group with another, or one person with one group. Its advantages benefit university students because they can use the institution's system that is installed into their devices.

- Interactive video-conferencing (IVC) allows the speaker, or in the case of education, the teacher, to deliver a live lecture to the student being together in one environment. To improve the effectiveness of this method, advanced configuration and aids from other media should be available.

- Web video-conferencing (WVC) offers the learner one priority, which is the flexibility of their whereabouts. Individuals can be at different places but are able to take part in the lesson. The interaction between the leaner and the teacher, and between learners themselves is also high. Furthermore, users of WVC do not need a software or a hardware because the meeting takes part on a website.

In teaching and learning, the role of video conferencing is getting more important. Along with the development of the World Wide Web, Internet users are now offered a chance to be wherever they are and still participate in a lesson effectively. As long as there is an interaction with the teacher and other learners, one can find their way through "zones of proximal development" (Vygotsky, 1978). According to Nesi (2004), this sociocultural theory of Vygotsky was adapted to some computer-mediated communication research (Debski, 1997; Levy, 1998; Warschauer, 1997), which provides the bases to a more thorough insight of VCTs in learning and teaching.

The role of video conferencing in learning may vary according to the requirements and the needs of teachers and learners. Mader and Ming (2015) provides a list of several significant roles that it plays in learning. Beside allowing HEIs to reach their farway students (Gillies, 2008), creating learner-centered courses (Beldarrain, 2006), varying learning styles (Greenberg \& Colbert, 2004), it can also trigger leadership skills and responsibility of the students (Gillies, 2008), among other benefits. 
In higher education, the role of video-conferencing started to be recognized in the early 21 st century (Wilkerson, 2004). HEIs use it to support distance classes, ensuring the amount and quality of interaction in the virtual classroom. Moody and Wieland (2010)finds that WiredRed Software Company's introduction of video-conferences which involved more than ten people in 2004 took it to another level. Two years after the event, more than half the number of U.S. higher institutions allowed the student to study online courses. Among them, three fourths reported using VCTs to assist teaching and learning (Parsad \& Lewis, 2008).

This form of education requires a good preparation from the teacher, the student, the institution, and its facility. Coventry (1995) raised the idea that ideally, the learner should be the core, and that technologies are fundamental but they should be adapted to the needs and the situations of the learner. He also suggests that a good insight of VCTs helps institutions make the most of them, so they must thoroughly comprehend the use of the tools. This in turn makes it a more complicated way of learning as the learner center must go alongside effective uses of the technologies.

While there have been studies of VCTs' effectiveness in education, they either focus on the impact of environmental or individual aspects on learning (Debski, 1997; Levy, 1998; Malinovski et al., 2012). Those studies, however, have not been able to adequately answer the questions of what chances and obstacles ICTs bring to higher education in order to stimulate the sharing of experiences in using them (Al-Samarraie, 2019). Additionally, there is a demand for a better perception of the qualifications and different situations in which lie the learners' acceptance, purpose, and use of VCTs among other technological learning tools ( Estriegana et al., 2019; Granic \& Marangunic, 2019), as well as an inadequate number of references of contemporary use of VCTs in developed and developing countries' higher education (Al-Samarraie, 2019) and users' attitude towards VCTs during COVID-19 (Granic \& Marangunic, 2019).

\section{Technology Acceptance Model}

First proposed by Davis (1989), TAM has been a popular and useful model for studying users' acceptance of information technology ( Estriegana et al., 2019; Legris et al., 2003). There were successive developments of TAM, namely, TAM2, UTAUT, and finally TAM3. TAM was built and developed based on the theory of reasoned action (TRA), which was proposed by Fishbein and Ajzen (1975), and emerged along at the same time of the Theory of Planned Behavior (TPB) (Abdullah and Ward, 2016; Chen et al., 2013; Chuttur, 2009; Wu, 2009). TAM was used to anticipate factual practices of particular activities based on a theory that they are in fact performances, so they can be analyzed and predicted with the aid from TRA model (Granic and Marangunic, 2019; Wu, 2009). TAM have been applied in diverse areas and in different ways, for instance, health care (Holden et al., 2010), online shopping (Singh et al., 2018), e-commerce (Fedorko et al., 2018), social media (Rauniar et al., 2014), and mobile banking (Sharma, 2019). The combination of TAM 2 (Venkatesh \& Davis, 2000) and Venkatesh's own model of perceived ease of use's most crucial factors (V.Venkatesh, 2000) provides a more advanced version of the acceptance of technology, TAM 3 mode (Venkatesh \& Bala, 2008).

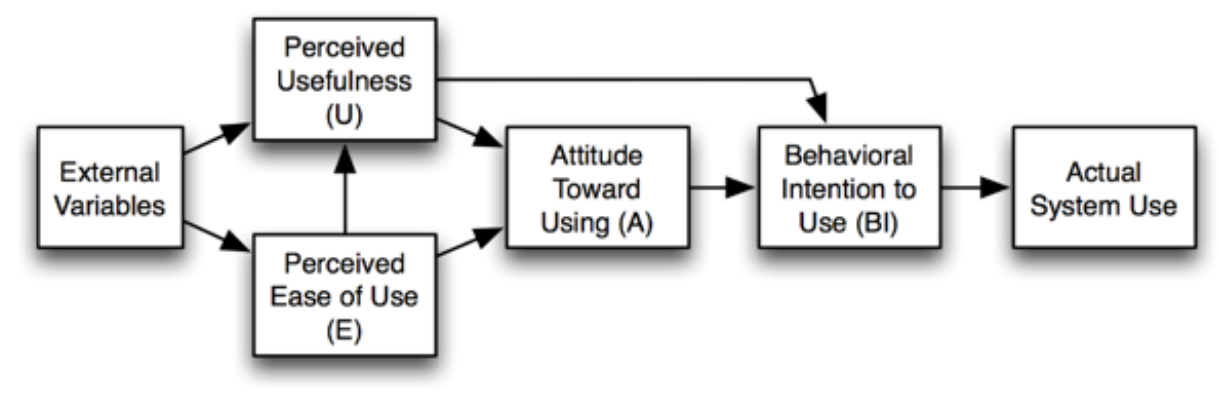

Figure 1. Technology acceptance model (Davis, 1989) 
For more than thirty years, TAM's validity, extension, and application have been widely researched in different contexts. Originally, TAM consists of crucial elements of user motivation (perceived usefulness, perceived ease of use, and attitude toward use) and outcomes (behavioral intentions, technology use or actual system use) (Scherer et al., 2019) (Figure 1). After a period of trials, researchers have come up with new factors and made adjustments to the link between already existing variables of TAM. They continually found new elements of important impacts on the model's core variables. This has helped TAM to enhance its role in expecting possible human's acceptance of reflection of technology (Granic and Marangunic, 2019). Venkatesh and Davis (2000) broaden out TAM 2 from TAM, using more theoretical conceptual elements related to practices like social impacts (subjective norms, voluntariness, image), and cognitive instruments (job relevance, output quality, result demonstrability, and perceived ease of use). TAM2 helps them explain more profoundly the factors connected to users and it is proved to be more effective in both contexts of voluntary or compulsory uses of technology. Nonetheless, Chuttur (2009) finds that users in voluntary environments are not influenced by subjective norms, while mandatory environments prove the opposite.

\section{Research Model and Hypotheses}

\section{Subject Norm}

Subjective norm (SN) is a direct determinant of behavioral intention in TRA (Fishbein and Ajzen,1975) and the subsequent TPB (Icek Ajzen, 1991). It is defined as "the degree to which an individual perceives that most people who are important to him think he should or should not use the system" (Fishbein and Ajzen,1975; Venkatesh and Davis, 2000). Davis (1989) express his opinion that people may have the decision prioritize a system or others' norms over their opinions. This factor is of interest to the TAM researcher as they concern the user's acceptance of new technologies.

Using TAM 2, Venkatesh and Davis (2000) indicated that subjective norm is the determinant of perceived usefulness (PU) that represent the social influence processes. Abdullah and Ward, (2016) analyze frequently employed external factors in previous research to study the development of a general extended TAM for e-learning. Their result demonstrates that out of 22 studies, 19 of them (86\%) point out a strong relation between $\mathrm{SN}$ and PU, which indicates that users' perceived utility is influenced by SN. Results of some study about TAM indicated that SN affected users' perceived ease of use (PEU) (Lemay et al., 2018; Revythi and Tselios, 2019).

Another research on engineering students' acceptance of an academic administrative information system in private universities in Lima, Peru found a substantial link between SN and attitude toward use new technologies (Jan \& Contreras, 2011). Research on direct impacts of SN on intention displays different outcomes. Some like Taylor and Todd's (1995) find particular influences, while some others show none (Davis, 1989; Lee, 2006; Mathieson, 1991). Nonetheless, some recent empirical studies on the adaption of new technology in teaching and learning point out $\mathrm{SN}$ influences behavioral intention to use (BI) most significantly (Al-gahtani, 2016; Al-harbi, 2011). Therefore, the following hypotheses were formulated:

H1a. Subject norm has a positive effect on perceived usefulness.

H1b. Subject norm has a positive effect on perceived ease of use.

H1c. Subject norm has a positive effect on attitude towards use.

H1d. Subject norm has a positive effect on behavioral intention to use.

\section{Output Quality}

According to Venkatesh and Davis (2000), output quality (OQ) is "the degree to which an individual believes that the system performs his or her job tasks well". This wellness is considered output quality. In this study, they also state that a profitability test is shown as viewpoints on output quality "in which, given a choice set containing multiple relevant systems, one would be inclined to choose a system that delivers the highest output quality".

In the empirically study about extrinsic and intrinsic motivation to use computers, Davis et al. (1992) indicated that output quality had significant effects on perceived usefulness. Less developed graded tests imply indirect impact of perceived ease of use and output quality on intentions through enjoyment and 
perceived usefulness (L. Li, 2010). Venkatesh and Bala (2008) suggest an increase of a system's job relevance, an improvement of output quality, and a lower concern of system use through adjustments and improvement activities. However, the previous study of Venkatesh and Davis (2000) deny the likeliness of judgments of output quality use in removing choices from the deliberation. These judgments are more likely to appear as effectiveness tests which lead to the choice of a system with the best output among various proper systems. As for the reasoning and prediction of perceived usefulness in TAM 3, Venkatesh and Bala (2008) found that output quality had an interactive effect on perceived usefulness such that with increasing output quality, the effect of job relevance on perceived usefulness was stronger. Hence, this hypothesis was proposed:

H2. Output quality has a positive effect on perceived usefulness.

\section{Computer Playfulness}

Venkatesh \& Davis (2000) point to anchors and adjustments as two prior factors to the perceived ease of use in order to determine TAM 2 perceived ease of use variables. They proposes that anchors are responsible for judgements of perceived ease of use, but those judgments may change as each user adopts new computer systems, related to which is computer playfulness represented by microcomputer playfulness (Viswanath Venkatesh \& Bala, 2008). Webster et al. (1992) described computer playfulness (CP) as "the degree of cognitive spontaneity in microcomputer interaction, where a high level of cognitive spontaneity indicates a high degree of playfulness and a low level of cognitive spontaneity indicates a low degree of playfulness".

Previous studies on users' new technology acceptance, especially students' acceptance, have identified and examined the links between CP and TAM's constructs. Venkatesh (2000) found that there is not a meaningful relationship between CP and PEU. However, many other studies show the opposite (Shen \& Eder, 2009; Sun \& Zhang, 2008; Zare \& Yazdanparast, 2013). Several previous studies suggest a clear link between users' positive ATT and CP (Moon \& Kim, 2001; Webster et al., 1990). Additionally, there is an opinion that perceived or computer playfulness is tightly related to PEU and PU. Sun and Zhang (2008) find an important relationship between $\mathrm{CP}$ and behavioral intention in technology use in their research on computer playfulness and perceived enjoyment. Therefore, the following hypotheses were developed:

H3a. Computer playfulness has a positive effect on perceived ease of use.

H3b. Computer playfulness has a positive effect on attitude toward using.

H3c. Computer playfulness has a positive effect on behavioral intention to use.

\section{Perceived Ease of Use}

Perceived ease of use (PEU) refers to "the degree to which a person believes that using a particular system would be free of effort (Davis, 1989). According to Davis (1989) and many study later, PEU is a direct determinant of PU (Dasgupta et al., 2002; W. H. Lee et al., 2018; Revythi \& Tselios, 2019). Additionally, technology acceptance in teaching and learning in previous studies implies a positive interaction between PEU and users' attitude (Bazelais et al., 2018; Calisir et al., 2014; Cheng, 2011; Masrom, 2007; Salloum et al., 2019).

For over three-decade, since Davis (1989) proposed the first TAM model, the relationship between PEU and $\mathrm{BI}$ or ASU has been analyzed in a number of empirical projects concerning PEU and its link to actual use of BI with mixed results (N. Park et al., 2014). In the period, several studies supported a relationship between PEU and BI or ASU (Park et al., 2009; Salloum et al., 2019; Venkatesh \& Davis, 2000), but others point to the less positive path (Dasgupta et al., 2002; Davis, 1989; S. Y. Park, 2009; Revythi \& Tselios, 2019).

In this research, we are going to examine the relationship between PEU and BI or ASU to determine how PEU influences students' attitude towards the use of VC tools, employing Hsu and Chang's (2013) result in Taiwan that PU affected ATT. The assumptions that we came up with were:

H4a. Perceived Ease of Use has a positive effect on perceived usefulness.

H4b. Perceived Ease of Use has a positive effect on attitude toward using.

H4c. Perceived Ease of Use has a positive effect on behavioral intention to use.

H4d. Perceived Ease of Use has a positive effect on actual system use. 


\section{Perceived Usefulness}

Perceived usefulness (PU) is a variable that plays the most important role in TAM. It is defined here as "the degree to which a person believes that using a particular system would enhance his or her job performance" (Davis, 1989). Some previous empirical studies point to PU as the most significant construct in TAM (Ayodele et al., 2016; Tan et al., 2012; Tarhini et al., 2017; Teng, 2014).

Other research demonstrates firm evidence for the link between users' attitude and PU (Akman \& Turhan, 2017; Al-Adwan et al., 2013; Wong, 2016). Significantly, Teo et al. (2008) suggest a close relationship between the high perceived usefulness and the more positive attitude.

In TAM 3, Venkatesh \& Bala (2008) find that perceived usefulness was the strongest predictor of behavioral intention at all time periods. Later on, some studies on e-learning in higher education imply a constructive relation between PU and the BI (Haryanto \& Kultsum, 2016; Hsia et al., 2014;Mahmodi, 2017).

H5a. Perceived usefulness has a positive effect on attitude toward using.

H5b. Perceived usefulness has a positive effect on behavioral intention to use.

\section{Attitude towards Use}

Fishbein and Ajzen's (1975) TRA model which introduces the first version of TAM suggests that a person's reaction to a certain behavior can be described as his/her perception on the performance of that behavior (Chuttur, 2009). Based on this definition, Davis, 1989 puts forward the idea of "an individual's overall affective reaction to use of the system" as an attitude towards the use of a new system. Moreover, the attitude towards the use can foretell behavioral intentions of information technology use among undergraduates and postgraduates students, among others (Cheng, 2019). Many studies about TAM in e-learning also showed that ATT has a direct impact on BI (Deshpande et al., 2012; Revythi \& Tselios, 2019; Sanchez-Franco et al., 2009; Stoel \& Lee, 2003; Vidanagama, 2016). Hence, the following hypothesis was developed:

H6. Attitude toward using has a positive effect on behavioral intention to use.

\section{Behavioral Intention to Use}

According to the theory of reasoned action (TRA), most behaviors are under volitional control and are predictable from behavioral intentions (Fishbein \& Ajzen, 1975). Venkatesh et al. (2003) defined behavioral intention to use a system (BI) as "the degree of an individual's belief that he or she will continue to use the system". Behavioral intentions refer to the belief that an individual will in fact perform a certain behavior (Ajzen \& Fishbein, 2005). In terms of the uses of technologies in learning, the behavioral intention (BI) refers to the intention of the learners to employ technologies and involves persistent use from the present to the future (Liao \& Lu, 2008). It has been shown by various studies that the behavioral intention directly and significantly influences the actual system use (ASU) (Al-gahtani, 2016; Mou et al., 2017; Teng, 2014). Hence, the following hypothesis is put forward:

H7. Behavioral intention to use has a positive effect on actual system use.

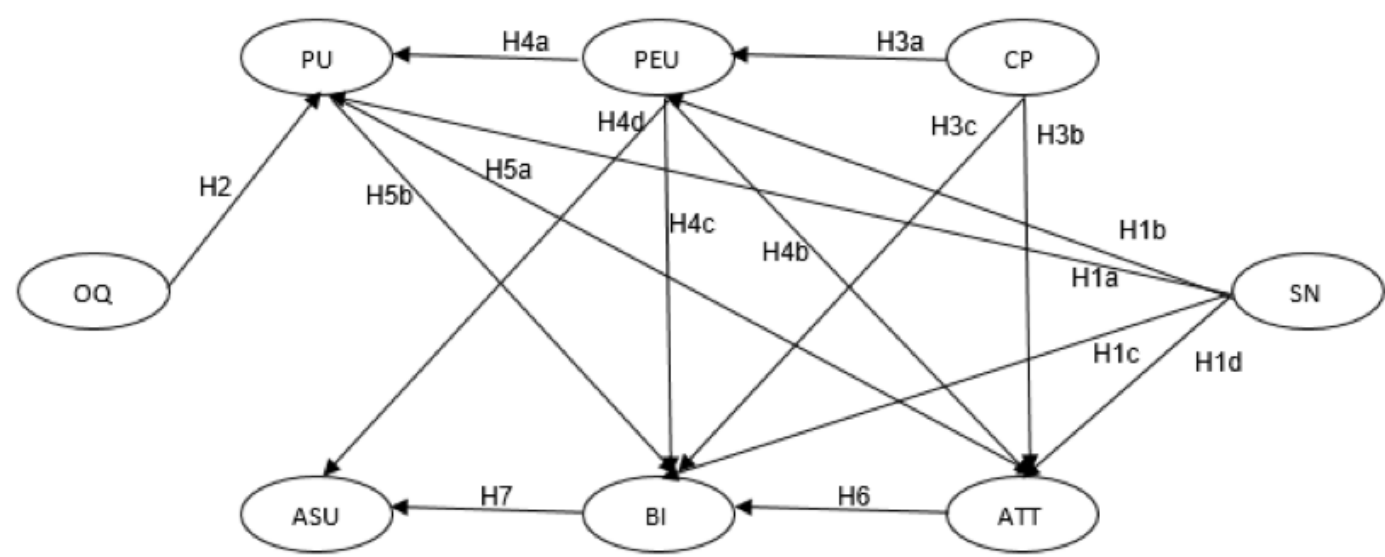

Figure 2. Research model 


\section{METHOD}

\section{Participants}

The participants of the research were students from universities in Hanoi who could not continue their traditional face-to-face learning because of COVID-19. To avoid the disruption, they were encouraged to adopt as e-learning oriented by their institutions. With the exception of a few universities which had already designed their own e-learning systems, VCTs were used by the majority of students in other universities to connect with their teachers. There was no limitation to the background of students, because this study was conducted to explore the level of acceptance of all participants in using VCTs. Its results could be biased if some specialized training related ICT were focused on. They could have been from any faculties and academic year, used any devices (desktops, laptops, smart phones, or tablets), been at any places to learn (cities or the countryside), and using any video conferencing applications. According to the collected data, 294 volunteer students have completed the questionnaire. After the screening of the data, 277 valid records of participants were used for the analysis. Detailed information of respondents was shown in Table 1 below.

Table 1. Demographics of respondents

\begin{tabular}{lcc}
\hline \multicolumn{1}{c}{ Variable } & Number & Ratio \\
\hline Academic year ( $\mathrm{N}=277)$ & 74 & \\
\hline 1 & 132 & 26.71 \\
2 & 47 & 47.65 \\
3 & 22 & 16.97 \\
4 & 2 & 7.94 \\
5 & & 0.72 \\
\hline Device $(\mathrm{N}=277)$ & 218 & \\
\hline Smartphone & 9 & 78.70 \\
Tablet & 194 & 3.24 \\
Laptop & 25 & 70.03 \\
Desktop & & 9.02 \\
Area $(\mathrm{N}=$ 277) & 128 & \\
Rural & 149 & 46.21 \\
Urban & & 53.79 \\
\hline
\end{tabular}

\section{Instrument}

Table 2 below presented the instrument of the research. According to this table, eight latent variables with 24 items were adopted, including OQ, CP, SN, PU, PEU, ATT, BI, and ASU. For all the measures, a fivepoint Likert type scale was used to gather all participants' perceptions, ranging from strongly disagree (1) to strongly agree (5). The structural equation modelling (SEM), which is the quantitative analysis method was applied to the survey data. The results were detailed in the Findings section

\section{Measurement}

The scales were designed based on the adjustment of Venkatesh and Davis' (2000) and Salloum's (2019) scales to match our research purposes. Table 2 below describes the scales and their reliability. All the subscales' reliability, Output Quality (alpha $=0.84)$, Perceived Usefulness (alpha $=0.93)$, Perceived Ease of Use (alpha $=0.86)$, Attitude towards Use (alpha $=0.91)$, Behavioral Intention to Use (alpha =0.89), Actual System Use $($ alpha $=0.82)$, Computer playfulness (alpha $=0.83)$, Subjective Norm (alpha $=0.87)$, were higher than 0.80 $(\mathrm{N}=277)$. The scales were designed using the research model presented in Figure 1. 
Table 2. Summary of measurement scales

\begin{tabular}{|c|c|c|c|c|}
\hline Construct & Measure & Mean (S.D.) & Loading & Source \\
\hline \multicolumn{5}{|c|}{ Output Quality (OQ) (composite reliability $=0.84$ ) } \\
\hline OQ1 & The quality of the output I get from VCT is high. & $3.03(0.95)$ & 0.91 & \multirow[t]{2}{*}{$\begin{array}{l}\text { (Venkatesh \& } \\
\text { Davis, 2000) }\end{array}$} \\
\hline OQ2 & I have no problem with the quality of VCTs output. & $3.04(1.08)$ & 0.81 & \\
\hline \multicolumn{5}{|c|}{ Computer playfulness $(\mathrm{CP})$ (composite reliability $=0.83$ ) } \\
\hline $\mathrm{CP} 2$ & I feel that VCT is enjoyable no matter what the usage purposes are. & $3.13(0.88)$ & 0.91 & \multirow{3}{*}{$\begin{array}{l}\text { (Salloum et } \\
\text { al., 2019) }\end{array}$} \\
\hline $\mathrm{CP} 4$ & $\begin{array}{l}\text { I feel that VCT helps me to improve my imagination by obtaining } \\
\text { information. }\end{array}$ & $2.94(0.91)$ & 0.84 & \\
\hline CP5 & $\begin{array}{l}\text { I feel that I can have a variety of experiences without any } \\
\text { interference. }\end{array}$ & $3.04(0.91)$ & 0.83 & \\
\hline \multicolumn{5}{|c|}{ Subjective Norm (SN) (composite reliability $=0.87$ ) } \\
\hline SN1 & $\begin{array}{l}\text { I should have participation in the VCT activities, as per my } \\
\text { instructors. }\end{array}$ & $3.58(0.92)$ & 0.93 & \multirow{2}{*}{$\begin{array}{l}\text { (Salloum et } \\
\text { al., 2019) }\end{array}$} \\
\hline SN2 & $\begin{array}{l}\text { I should have participation in the VCT activities, according to other } \\
\text { students. }\end{array}$ & $3.48(0.86)$ & 0.83 & \\
\hline \multicolumn{5}{|c|}{ Perceived Usefulness (PU) (composite reliability $=0.93$ ) } \\
\hline PU1 & VCT enhances my learning performance. & $2.81(0.99)$ & 0.89 & \multirow{4}{*}{$\begin{array}{l}\text { (Salloum et } \\
\text { al., 2019) }\end{array}$} \\
\hline PU2 & $\begin{array}{l}\text { My productivity is elevated through the utilization of VCT in my } \\
\text { study. }\end{array}$ & $2.80(0.99)$ & 0.93 & \\
\hline PU3 & Using VCT enhances my learning effectiveness. & $2.75(0.97)$ & 0.91 & \\
\hline PU4 & I find VCT to be useful in my learning. & $3.07(0.93)$ & 0.84 & \\
\hline \multicolumn{5}{|c|}{ Perceived Ease of Use (PEU) (composite reliability $=0.86$ ) } \\
\hline PEU1 & I find it easy to get VCT to do what I want it to do. & $3.19(0.87)$ & 0.78 & \multirow{4}{*}{$\begin{array}{l}\text { (Venkatesh \& } \\
\text { Bala, 2008) }\end{array}$} \\
\hline PEU2 & VCT is easy to use for me. & $3.62(0.91)$ & 0.82 & \\
\hline PEU3 & Interacting with VCT does not require a lot of my mental effort. & $3.31(1.00)$ & 0.76 & \\
\hline PEU4 & My interaction with VCT is clear and understandable. & $3.45(0.87)$ & 0.86 & \\
\hline \multicolumn{5}{|c|}{ Attitude Towards Use (ATT) (composite reliability = 0.91) } \\
\hline ATT1 & I feel positive regarding the utilization of VCT. & $3.20(0.87)$ & 0.87 & \multirow{3}{*}{$\begin{array}{l}\text { (Salloum et } \\
\text { al., 2019) }\end{array}$} \\
\hline ATT2 & In general, I admire the utilization of VCT. & $2.97(0.95)$ & 0.90 & \\
\hline ATT3 & VCT provides an attractive learning environment. & $2.96(0.93)$ & 0.89 & \\
\hline \multicolumn{5}{|c|}{ Behavioral Intention to Use $(\mathrm{BI})($ composite reliability $=0.89)$} \\
\hline Bl1 & I will make use of VCT regularly in the forthcoming time. & $3.23(0.95)$ & 0.80 & \multirow{4}{*}{$\begin{array}{l}\text { (Salloum et } \\
\text { al., 2019) }\end{array}$} \\
\hline $\mathrm{BI} 2$ & $\begin{array}{l}\text { I intend to make use of functions of VCT for providing assistance to } \\
\text { my academic activities. }\end{array}$ & $3.34(0.89)$ & 0.85 & \\
\hline $\mathrm{BI} 3$ & I will give out my recommendation to others to use VCT. & $3.20(0.90)$ & 0.80 & \\
\hline $\mathrm{BI} 4$ & I will use VCT on a regular basis in the future. & $3.10(0.91)$ & 0.86 & \\
\hline \multicolumn{5}{|c|}{ Actual System Use (ASU) (composite reliability $=0.82$ ) } \\
\hline ASU1 & I use VCT frequently. & $3.11(0.97)$ & 0.99 & \multirow{2}{*}{$\begin{array}{l}\text { (Salloum et } \\
\text { al., 2019) }\end{array}$} \\
\hline ASU2 & I use the VCT on a daily basis. & $2.98(1.00)$ & 0.71 & \\
\hline
\end{tabular}

\section{Online Survey}

During the social distancing period, an online survey was the most effective method to collect data. A questionnaire was designed on Google Forms and was distributed to the participants using the snowball data collection method. In the first step, the questionnaire was sent to the managerial staff and lecturers of different universities to make sure the questions were simple enough to understand before it reached the students via email. The students were encouraged to spend 15 to 20 minutes on the questionnaire, although 
they were to decide whether they would do it or not. Those who had completed the survey were encouraged to invite their peers who also used VCTs in distance learning to do the questionnaire. Data were collected in 10 days, from April 14, 2020 to April 23, 2020, and no more data was accepted after that day. The initial set of data consisted of 294 records. After a general observation, 17 records were discarded because the participants only provided a constant value for all questions. The last data set of 277 records were analyzed on the SPSS 20 statistical analysis software, and the research model and hypotheses were tested on the AMOS 23 structural analysis software.

\section{Confidentiality}

All the information in this survey, including the research purpose, the amount of time to fill all items, the contact of the research group, and the guarantee of information confidentiality were provided to participants at the beginning of the questionnaire. There were notified volunteers who answered all the questions, thus they joined the survey on a voluntary basis. The questionnaire just collected information to support this research whose data were analyzed by members of the research team. There was no funding for the gathering and analysis of the data. All the information of respondents were used for research purposes, and personal information and responses from the students were kept confidential by the whole team.

\section{FINDINGS}

\section{Measurement Model}

To exemplify the competence of the measurement model with AMOS 23, we adopted the confirmatory factor analysis (CFA). The model fit, convergent validity, and discriminant validity were used to assess the measurement models' sufficiency. A good model fit's minimum input is illustrated in Table 3. The maximum level of the Chi-square value multiplied by the freedom value (x2/d.f.) is 3 (Vandenberg, 2006), of adjusted goodness of fit index (AGFI) is 0.80 (Forza \& Filippini, 1998), of comparative fit index (CFI) is 0.9 (F. Hair et al., 2010), of non-normed fit index (NNFI) and root mean square error of approximation (RMSEA) is 0.08 (Awang, 2012). Our research's result implied a sufficient model fit, with $\mathrm{x} 2 /$ d.f. in CFA model being 1.674 ( $\mathrm{x} 2-363.270$; d.f. $=217$ ), AGFI being 0.866 , NFI being 0.933 . CFI being 0.972 , and RMSEA being 0.049 . The composite reliability value presented in Table 1 was adopted to measure the reliability, which showed the result of over 0.80 . This suggests a generally accepted degree of confirmatory research. Fornell and Larcker's (1981) criteria were used to determine the convergent validity. They propose that every indicator factor loadings ought to be notable and be no higher than 0.70 , and that each item's average variance extracted (AVE) ought to be higher than 0.50, which is the variance owing to the glitch of measurement. Among all items in the study, most of them were measured over 0.70 on their individual construct. These figures were able to verify the adequate item convergence on the intended construct. However, the third item of both computer self-efficacy and social influence were lower than 0.70 . Because of some glitches in measurement, AVE level was higher than the variances, fluctuating between 0.643 and 0.797 (Table 3). All of the above figures led to our conclusion that the convergent validity conditions were satisfied. Fornell and Larcker also state that AVE's square root from a construct ought to be higher than the shared value between itself and others in the model in order to reach an adequate discriminant validity. This discriminant validity was sufficient because the inter-construct correlations' level was lower than that of the diagonal values. From these points, we were able to disclose a relatively high construct validity of the measurement. 
Table 3. Squared correlations of latent variables

\begin{tabular}{lcccccccccc}
\hline Construct & CR & AVE & ATT & PEU & PU & BI & ASU & OQ & CP & SN \\
\hline ATT & 0.918 & 0.789 & $\mathbf{0 . 8 8 8}$ & & & & & & & \\
PEU & 0.878 & 0.643 & 0.760 & $\mathbf{0 . 8 0 2}$ & & & & & & \\
PU & 0.940 & 0.797 & 0.813 & 0.594 & $\mathbf{0 . 8 9 3}$ & & & & & \\
BI & 0.895 & 0.681 & 0.757 & 0.629 & 0.667 & $\mathbf{0 . 8 2 5}$ & & & & \\
ASU & 0.851 & 0.745 & 0.520 & 0.455 & 0.508 & 0.752 & $\mathbf{0 . 8 6 3}$ & & & \\
OQ & 0.849 & 0.738 & 0.604 & 0.567 & 0.593 & 0.550 & 0.437 & $\mathbf{0 . 8 5 9}$ & & \\
CP & 0.900 & 0.751 & 0.694 & 0.603 & 0.625 & 0.713 & 0.535 & 0.575 & $\mathbf{0 . 8 6 6}$ & \\
SN & 0.878 & 0.783 & 0.496 & 0.589 & 0.385 & 0.534 & 0.261 & 0.475 & 0.481 & $\mathbf{0 . 8 8 5}$ \\
\hline
\end{tabular}

Diagonal elements (in bold) are the square root of the average variance extracted (AVE). Off-diagonal elements are the correlations among constructs. Diagonal elements must be larger than off-diagonal elements for discriminant validity. PEU $=$ Perceived Ease of Use; PU = Perceived Usefulness; ATT = Attitude towards Use; BI = Behavioral Intention to Use; ASU = Actual System Use; SN = Subjective Norm; OQ = Output Quality; $\mathrm{CP}=$ Computer playfulness.

\section{Model Testing Results}

This research tested the general fit and advantages of the assumptions. Table 4 presented the fit indices were $1.665(\mathrm{x} 2=374.746$; d.f. -225$)$ and AGFI $=0.876, \mathrm{NFI}=0.931, \mathrm{CFI}=0.971$, and RMSEA $=0.049$ which were in the right range. This result indicated a legitimate fit of the model into the data. The hypotheses are presented in Figure 3 and generalized in Table 5, with 11 out of 16 items' p-value lower than 0.05 . The descriptive strength of the model were also exhibited.

Table 4. Overall model fit indices for the research model

\begin{tabular}{lccc}
\hline \multicolumn{1}{c}{ Model fit indices } & Results & Recommended value & Source \\
\hline Chi-square statistic & $1.665(374.746 / 225)$ & $\leq 3$ & Vandenberg (2006) \\
AGFI & 0.867 & $\geq 0.80$ & Forza \& Filippini (1998) \\
CFI & 0.971 & $\geq 0.90$ & F. Hair et al. (2010) \\
NFI & 0.931 & $\geq 0.90$ & Awang (2012) \\
RMSEA & 0.049 & $<0.08$ & Awang (2012) \\
\hline
\end{tabular}

\section{Hypothesis Testing Results}

Regarding path analyses, eleven hypotheses in this study are supported by our empirical analysis of SEM; nonetheless, the other five not. Specifically, OQ had a direct effect on PU $(\beta=0.43, t=6.43)$. Therefore, Hypotheses 2 are supported. Regarding the role of $S N$, there is a considerable variation concerning influence on PEU, PU, ATT, BI. Two of four paths starting from SN and ending at PEU and BI showed significant results: $\mathrm{SN}-\mathrm{PEU}(\beta=0.40, \mathrm{t}=6.18) ; \mathrm{SN}-\mathrm{BI}(\beta=0.12, \mathrm{t}=2.20)$. Two of four paths starting from $\mathrm{SN}$ and ending at PU and ATT showed insignificant results: $\mathrm{SN}-\mathrm{PU}(\beta=0.06, \mathrm{t}=0.89)$; $\mathrm{SN}-\mathrm{BI}(\beta=0.01, \mathrm{t}=$ 0.27). Thus, hypotheses $1 \mathrm{~b}, 1 \mathrm{c}$ are supported; Hypotheses $1 \mathrm{a}, 1 \mathrm{~d}$ are not supported. Regarding the role of $\mathrm{CP}$, a significant impact on PEU, ATT, and BI was observed. All three paths starting from $\mathrm{CP}$ and ending at PEU, ATT, BI showed significant results: CP - PEU $(\beta=0.40, t=6.26), C P-A T T(\beta=0.16, t=3.08)$, $\mathrm{CP}$ - BI $(\beta=0.33, \mathrm{t}=4.75)$. Therefore, Hypotheses $3 \mathrm{a}, 3 \mathrm{~b}, 3 \mathrm{c}$ are supported. 
Regarding the latent variable PEU, the dependent variables, PU, ATT, BI, and ASU were greatly influenced. Two paths starting from SN and ending at PU and ATT have significant results: PEU - PU $(\beta=0.21, t$ $=2.92)$, PEU - ATT $(\beta=0.34, t=6.05)$. Other paths starting from SN and ending at BI and ASU have insignificant results: PEU - BI $(\beta=0.03, t=0.40)$, PEU - ASU $(\beta=-0.46, t=-0.73)$. Thus, hypotheses 4a, $4 \mathrm{~b}$ are supported; hypotheses $4 \mathrm{c}, 4 \mathrm{~d}$ are not supported. The examination of hypotheses which stem from the latent variable PU and included dependent variables ATT and BI showed that the path starting from PU and ending at ATT showed significant result: PU - ATT $(\beta=0.51, t=9.41)$ : the path starting from PU and ending at BI showed insignificant result: PU - BI $(\beta=0.11, t=1.43)$. Thus, hypotheses $5 \mathrm{a}$ is supported and hypotheses $5 \mathrm{~b}$ is not supported. The significant result of testing the path starting from ATT and ending at BI: ATT - BI $(\beta=0.33, t=2.93)$ shows the influence of ATT on BI. Consequently, there is the significant result of testing the path starting from BI and ending at ASU: BI - ASU $(\beta=0.78, t=10.78)$. Therefore, hypotheses 6, 7 are supported.

Table 5. Results of all hypothesis testing

\begin{tabular}{|c|c|c|c|c|}
\hline Variable & Path Coefficient $(\beta)$ & $\mathrm{t}$ & Hypotheses & Result \\
\hline \multicolumn{5}{|c|}{ Dependent Variable: PU } \\
\hline SN & 0.06 & 0.89 & $\mathrm{H} 1 \mathrm{a}$ & Not supported \\
\hline $\mathrm{OQ}$ & 0.43 & $6.34^{* * *}$ & $\mathrm{H} 2$ & Supported \\
\hline PEU & 0.21 & $2.92^{* *}$ & $\mathrm{H} 4 \mathrm{a}$ & Supported \\
\hline \multicolumn{5}{|c|}{$R^{2}: 39.2 \%$ of the variance of PU are explained by $O Q$ and PEU } \\
\hline \multicolumn{5}{|c|}{ Dependent Variable: PEU } \\
\hline SN & 0.40 & $6.18^{* * *}$ & $\mathrm{H} 1 \mathrm{~b}$ & Supported \\
\hline $\mathrm{CP}$ & 0.40 & $6.26^{* * *}$ & $\mathrm{H} 3 \mathrm{a}$ & Supported \\
\hline \multicolumn{5}{|c|}{$\mathrm{R}^{2}: 39.2 \%$ of the variance of PEU are explained by $\mathrm{CP}$ and $\mathrm{SN}$} \\
\hline \multicolumn{5}{|c|}{ Dependent Variable: ATT } \\
\hline SN & 0.01 & 0.27 & $\mathrm{H} 1 \mathrm{~d}$ & Not supported \\
\hline $\mathrm{CP}$ & 0.16 & $3.08^{* *}$ & $\mathrm{H} 3 \mathrm{~b}$ & Supported \\
\hline PEU & 0.34 & $6.05^{* * *}$ & $\mathrm{H} 4 \mathrm{~b}$ & Supported \\
\hline PU & 0.51 & $9.41^{* * *}$ & $\mathrm{H} 5 \mathrm{a}$ & Supported \\
\hline \multicolumn{5}{|c|}{$\mathrm{R}^{2}: 71.2 \%$ of the variance of ATT are explained by PU, PEU, and CP } \\
\hline \multicolumn{5}{|c|}{ Dependent Variable: $\mathrm{BI}$} \\
\hline SN & 0.12 & $2.20^{*}$ & $\mathrm{H} 1 \mathrm{c}$ & Supported \\
\hline $\mathrm{CP}$ & 0.33 & $4.75^{* * *}$ & $\mathrm{H} 3 \mathrm{C}$ & Supported \\
\hline PEU & 0.03 & 0.40 & $\mathrm{H} 4 \mathrm{C}$ & Not supported \\
\hline PU & 0.11 & 1.43 & $\mathrm{H} 5 \mathrm{C}$ & Not supported \\
\hline ATT & 0.33 & $2.93 * *$ & $\mathrm{H} 6$ & Supported \\
\hline \multicolumn{5}{|c|}{$\mathrm{R}^{2}: 57.7 \%$ of the variance of $\mathrm{BI}$ are explained by $\mathrm{ATT}, \mathrm{SN}$, and CP } \\
\hline \multicolumn{5}{|c|}{ Dependent Variable: ASU } \\
\hline PEU & -0.46 & -0.73 & $\mathrm{H} 4 \mathrm{~d}$ & Not supported \\
\hline $\mathrm{BI}$ & 0.78 & $10.78^{* * *}$ & $\mathrm{H} 7$ & Supported \\
\hline
\end{tabular}

Note: $P E U=$ Perceived Ease of Use; $P U=$ Perceived Usefulness; $A T T=$ Attitude towards Use; $B I=$ Behavioral Intention to Use; $A S U=$ Actual System Use; $S N=$ Subjective Norm; $O Q=$ Output Quality; $C P=$ Computer playfulness.

Note: ${ }^{*} p<0.05{ }^{* *} p<0.01 ;{ }^{* * *} p<0.001$ 


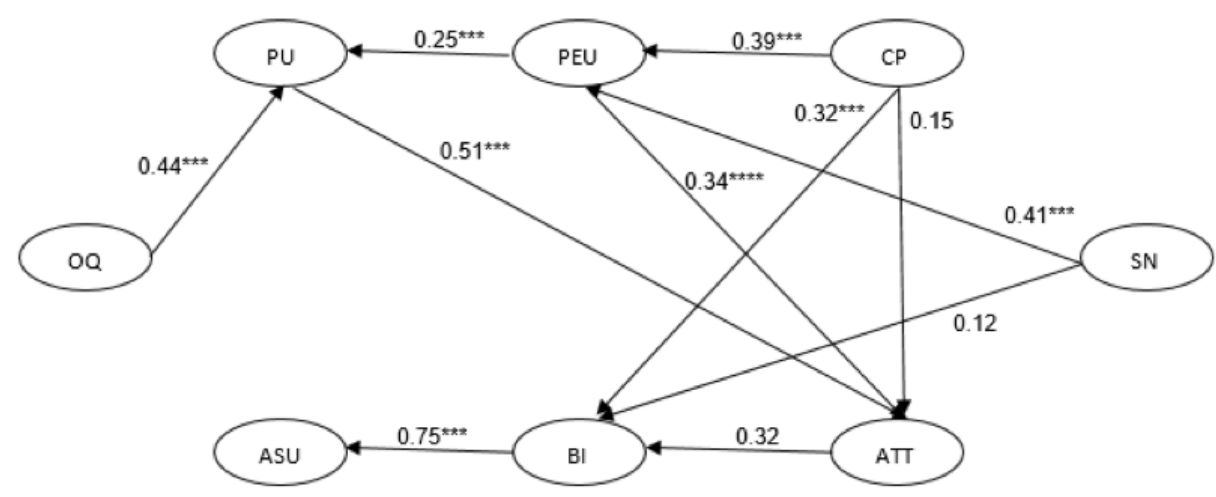

Figure 3. Result of testing model $\left({ }^{*} \mathrm{p}<0.05\right.$; $^{* *} \mathrm{p}<0.01$; $\left.^{* * *} \mathrm{p}<0.001\right)$

\section{DISCUSSION}

Through the review of literature on distance learning and VCTs, we developed the extension of TAM with three external factors: subject norm, output quality, computer playfulness, to understand students' acceptance of VCTs as tools to support their distance learning during the stay-at-home period caused by COVID-19 pandemic. The results were discussed from the spectacles of TAM constructs and the external factors.

Regarding TAM constructs, our research matches both TAM uses and previous studies' results of technology acceptance among students of higher-education level. PU and ATT of VCTs in distance learning are proven to be highly and positively influenced by PEU, which conform to the theoretical base of TAM proposed by David and the previous studies ( Al-Rahmi et al., 2019; Dumpit and Fernandez, 2017; Chang et al., 2017; Hanif et al., 2018; Moon and Kim, 2001). The result also corresponds to the hypothesis that a perception of VCTs as user-friendly and easy to use leads to an increase in its usefulness and attitudes (Salloum et al., 2019).

Also pointed out from the result is a considerably positive impact of PU on how students reacted to VCTs. Their attitudes also emphatically affected the behavioral intention, which is strongly related to VCTs' actual use in distance learning. These results also match with the original hypotheses of TAM (Davis, 1989; Hsu \& Chang, 2013; Revythi \& Tselios, 2019). Students' attitude towards VCTs use in COVID-19 would be improved as they deem them to be useful. The findings can be traced back to the idea that students' behavioral intention would level up as their positive attitudes towards VCTs in distance education are shown. This in turn leads to a better actual use (Salloum et al., 2019). In Vietnam, distance and online learning are not yet popular and thus, Vietnamese students are not used to these ways of learning. Nonetheless, in such a period of social distancing, the results from the empirical examination of TAM constructs show that the students could adapt to the VCTs and use them rather easily, as well as seeing that VCTs are helpful tools to ensure the continuity of education. As a result, they had a positive attitude towards the use of VCTs in distance learning. In terms of the external factors, and the adoption of VCTs in distance learning, first, the results are able to certify the positive effects of SN on PEU (Abdullah \& Ward, 2016; Revythi \& Tselios, 2019) and BI (Al-gahtani, 2016; S. Y. Park, 2009; Tarhini et al., 2017; Taylor \& Todd, 1995), which corresponds to previous studies and TAM 2. Nonetheless, it is shown that $\mathrm{SN}$ does not significantly influenced to PU and ATT, while a number of the previous studies point to the former's impact on PU (Rejón-Guardia et al., 2013) and ATT (Jan and Contreras, 2011). The above mentioned outcomes suggest that their universities, their instructors, and their peers neither make students deem VCTs as effective in distance learning, nor improve their attitudes on the encouragement to use them. Meanwhile, students' awareness on the ease of use depends on those who think they can adopt the tools easily in distance learning. During COVID-19's social distancing period, the external factors resulting from the guarantee of teaching and learning quality played an important role in students' intention to use and their actual use of VCTs in distance learning.

Secondly, these results of the research postulated that OQ has a significant positive impact on PU. The higher the output quality, the better students are aware of VCTs' helpfulness in distance learning. This outcome supports W. H. Lee et al. (2018) on output quality's impact on the customer's acceptance of use of 
restaurant service robots in ordering and delivering food. This suggests that the PU of the new technology can be built up through the high output quality. As a result, high output quality indirectly but positively affects actual system use through underdeveloped variables like ATT and BI.

Thirdly, concerning students' adoption of VCTs in distance learning, CP substantially and positively affects PEU, ATT, and BI. As students' cognitive spontaneity in computer interaction improves, they have better awareness of the ease of use, better attitude, and higher intention to use VCTs. All CP-related results can be explained using the theory of intrinsic motivation, specifically, the self-determination theory (V. Venkatesh, 2000). Deci and Ryan (1985) propose that intrinsic motivation in learning is based on one's autonomy to make choices, the challenges in the activity, and the ability to obtain it. The users who are more playful with computers have better interaction with IS than those who are less. They also consider the challenges in a technology positive, considering it as a chance to savor rather than an obstacle to overcome. In the context of almost compulsory distance learning during COVID-19, students' awareness and attitude towards VCTs may effectively be shaped by their perceived playfulness.

The empirical results show that the external factors OQ, SN, and CP had positive influences on the Vietnamese student's acceptance of VCTs as a tool to interact with the lecturer in distance learning, and that those factors were the participants' advantages in distance learning. The research, however, does not find any elements that hindered or caused difficulties to the participants when they adapt this learning style in Vietnam.

In a nutshell, because both sensitive situations and various factors have influences on TAM's core (AlEmran et al., 2018), some of the factors were not supported in COVID-19 pandemic context in Vietnam. This disadvantage calls for further studies on external factors related to the acceptance of VCTs in distance learning. The recognition of these factors will provide a better background on students' awareness and attitude towards VCTs as distance learning tools in COVID-19 context, thus, improve the future acceptance rates of these tools in learning.

\section{Practical Implications and Recommendations}

Global education seems to change forever in the context of COVID-19. The adoption of technology in higher education is of higher speed than ever before in order to ensure the quality of distance teaching and learning (Credit Suisse, 2020; Li \& Lalani, 2020; World Bank, 2020). In such a situation, this research examined the relationship between TAM constructs and external factors to emphasize the appliance of TAM model. An insight of the external factors was also provided, and practical implications about VCTs use in distance education are made for the research community about distance learning, managers, instructors, and service providers.

The research's results may serve as a helpful reference for the research community if they want to go further into the comparison between distance learning issues among countries with diverse contexts, or different stages of the COVID-19 pandemic. At the same time, they could be a constructive source of information for policy makers in building strategies for distance learning.

Decision makers and managers in Vietnam's HEIs need to employ VCTs to guarantee students' learning when they cannot come to class, and at the same time consider it a tool for the future of blended learning, the form which combine face-to-face and computer-based instruction (Garrison and Kanuka, 2004; Graham, 2006). Decisive elements in improving students' acceptance, teaching performances and students' competence should be the focal point of those models. Institutions should therefore organize VCTs training courses to encourage and raise students' awareness on their efficiency and ease of use in both traditional and distance education. This will in turn lead to the extrinsic and intrinsic motivations among students.

Moreover, the instructor has influences the student on many aspects of learning, including their acceptance of technology use and communication (Abu-al-aish \& Love, 2013; Igbaria et al., 1994; Karahanna et al., 1999; Leonard-Barton \& Deschamps, 1998). Therefore, the instructor ought to support the student more effectively when they have obstacles in using the technologies, as well as creating a friendlier VCTs-based learning environment for the student. 
Furthermore, external factors related to students' acceptance of VCTs use in distance learning were proved to be important. As a result, the Internet and video conferencing service suppliers need to provide and develop VCTs' functions with the aim of a user-friendly environment for students' interaction, creating the cognitive spontaneity between users and the tools to encourage intrinsic motivation. At the same time, institutions ought to enhance the quality of the Internet connection to ensure a high quality of teaching and learning.

\section{Limitation}

Although the study revealed interesting results that essentially contribute to the description of students' acceptance of e-learning systems, it also posits some limitations. The outcomes of the research are constructive for future projects concerning a shift from the traditional form of education to e-learning, or learning supported by online systems in those regions with the same economic context as Vietnam. Nonetheless, the limitations should be further discussed. Firstly, the snowball sampling technique adopted in this research is not able to be applied on every student. If other sampling techniques are to be applied in future studies, a more general outcome might be expected. Secondly, because this research focused on public universities in Vietnam, the result only showed a pattern of public but not private universities. Thirdly, elements of COVID-19 context were not a part of the research model to evaluate the direct influences of students' attitude and behavior. The indirect impacts from COVID-19 in the study, which were related to the use of VCTs, lie beneath obvious outcomes.

\section{CONCLUSION}

After the examination of the Vietnamese students' acceptance of using VCTs in distance learning during the COVID-19 pandemic, we concluded that most TAM constructs received notable impacts from external factors. In particular, the result shows that:

- The subject norm had a positive effect on the perceived ease of use and the attitude towards use

- The output quality had a positive effect on the perceived usefulness

- The computer playfulness had a positive effect on the perceived ease of use, the attitude towards using, and the behavioral intention to use

- The perceived ease of use had a positive effect on the perceived usefulness and the attitude toward using

- The perceived usefulness had a positive effect on the attitude towards using

- The attitude towards using had a positive effect on the behavioral intention to use

- The behavioral intention to use had a positive effect on the actual system use.

As mentioned earlier, the face of global education is going to change forever after the COVID-19 pandemic. This is a chance for HEIs to test various forms of teaching and learning and see what can be adopted into their curricula. The assistance of technologies, especially VCTs, plays an important role in shaping the future of blended- learning in Vietnam. As long as the VCTs are able to motivate students both extrinsically and intrinsically, a positive attitude from the students can be expected. From the result of this research, the managers, instructors, and service providers can find ways to make more effective decisions to increase the students' acceptance of VCTs, especially in the context of unexpected changes.

To reach this goal, the function of VCTs should be developed and adjusted to fit the context in Vietnam and to attract more users. Further research may investigate both public and private educational institutions of all levels using a wider range of sampling techniques to a better understanding of VCTs in Vietnam. If this is to be achieved, a new age of education will soon be opened.

Acknowledgements: The authors of this article are extremely thankful to all the students who participated in this study, along with the managerial staff and lecturers who commented on the questionnaires. 


\section{BIODATA and CONTACT ADDRESSES of AUTHORS}

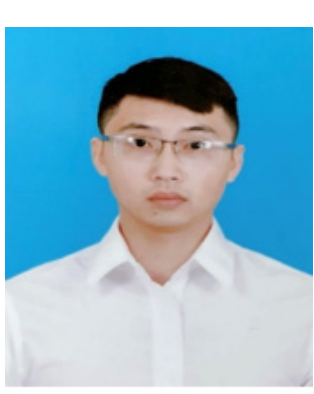

Xuan-An NGUYEN is an researcher fellow at the Vietnam National Institute of Educational Sciences. He has received the BSc degree in information technology from Hanoi University of Mining and Geology in 2012; BSc degree in educationa management from Hanoi National University of Education in 2015 and MSc degree educationa management from Hanoi National University of Education in 2016. His academic interest areas are open and distance education, online learning, e-learning, information communication technology in education, higher education, education management, education policy. He has four journal articles published in international indexes.

\section{Xuan-An NGUYEN}

The Vietnam National Institute of Educational Sciences

Address: The Vietnam National Institute of Educational Sciences, 100000, Hanoi, Vietnam Phone: +84978413717

E-mail: annx@vnies.edu.vn / nguyenxuanan89@gmail.com

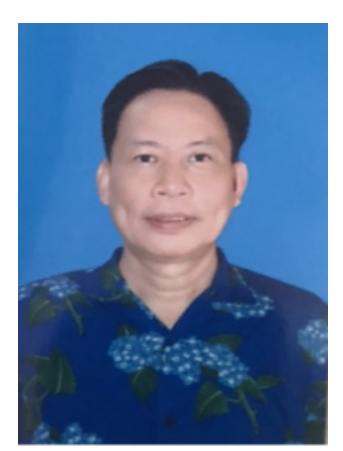

Dr. Duc-Hoa PHO is an Associate Professor and PhD in Education at Ha Noi National University of Education. Dr. Pho Duc Hoa gained his Ph.D. in Educational Technology at July, 2005. He graduated from Leningrad Pedagogical University, now Saint Petersburg in 1985, and defended his $\mathrm{PhD}$ thesis in 1996. His research works mainly focus on constructivism in education; teaching technology in pedagogical environment. Interactive; assess learners towards capacity development; educational management and school administration. Recently, he is the Editor-in-Chief of the Textbook of Experiential Activities in Primary School (of Vietnam Education Publishing House). He has taught undergraduate and graduate students for more than 35 years; successfully guided 12 doctorates, more than 100 masters in Education and Educational Management; has published more than 15 textbooks, monographs and reference books; is the author of nearly 50 scientific articles at home and abroad; Currently, he is working at the Faculty of Primary Education, University of Education and Science (faculty of Priamry Education; HaNoi National University)

\section{Duc-Hoa PHO}

Faculty of Primary Education

Address: Ha Noi National University of Education, 100000, Hanoi, Vietnam

Phone: +84913379716

E-mail: hoapd40@gmail.com

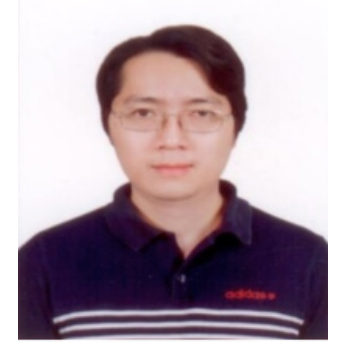

Dinh-Hai LUONG is an IT technician of the Vietnam National Institute of Educational Sciences. He gained master in Infomation Systems in 2013. His academic interest areas are open and distance learning, e-learning, information communication technology in education, learning management systems, library and information science, open educational resources. He has five journal articles published in international indexes, three international articles, papers submitted to international meetings.

\section{Dinh-Hai LUONG}

The Vietnam National Institute of Educational Sciences

Address: The Vietnam National Institute of Educational Sciences, 100000, Hanoi, Vietnam

Phone: +84983005483 ,

E-mail: luongdinhhai@vnies.edu.vn / luongdinhhai@gmail.com 


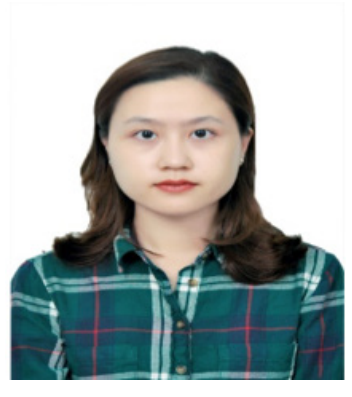

Xuan-Thuc-Anh CAO

English Department

Address: Hanoi University, 100000, Hanoi, Vietnam

Phone: +84976320009

E-mail: thucanhcaoxuan@gmail.com

\section{REFERENCES}

Abdullah, F., \& Ward, R. (2016). Developing a General Extended Technology Acceptance Model for E-Learning (GETAMEL) by analysing commonly used external factors. Computers in Human Behavior, 56, 238-256.

Abu-al-aish, A., \& Love, S. (2013). Factors Influencing Students' Acceptance of M-Learning: An Investigation in Higher Education. International Review of Research in Open and Distributed Learning, 14(5), 82-107.

Ajzen, I., \& Fishbein, M. (2005). The influence of attitudes on behavior. In D. Albarracin, B. T. Johnson, \& M. P. Zanna (Eds.), The handbook of attitudes (p. 173-221). Lawrence Erlbaum Associates Publishers.

Ajzen, Icek. (1991). The theory of planned behavior. Organizational Behavior and Human Decision Processes, 179-211.

Akman, I., \& Turhan, C. (2017). User acceptance of social learning systems in higher education: an application of the extended Technology Acceptance Model. Innovations in Education and Teaching International, 54(3), 229-237.

Al-Adwan, A., Al-Adwan, A., \& Smedley, J. (2013). Exploring Students Acceptance of E-Learning Using Technology Acceptance Model in Jordanian Universities. International Journal of Education and Development Using Information and Communication Technology, 9(2).

Al-Emran, M., Mezhuyev, V., \& Kamaludin, A. (2018). Technology Acceptance Model in M-learning context: A systematic review. Computers and Education, 125, 389-412.

Al-gahtani, S. S. (2016). Empirical investigation of e-learning acceptance and assimilation: A structural equation model. Applied Computing and Informatics, 12(1), 27-50.

Al-harbi, K. A. (2011). e-Learning in the Saudi tertiary education: Potential and challenges. Applied Computing and Informatics, 9(1), 31-46.

Al-Maroof, R. A. S., \& Al-Emran, M. (2018). Students acceptance of google classroom: An exploratory study using PLS-SEM approach. International Journal of Emerging Technologies in Learning, 13(6), $112-123$.

Al-Samarraie, H. (2019). A scoping review of videoconferencing systems in higher education: Learning paradigms, opportunities, and challenges. International Review of Research in Open and Distance Learning, 20(3), 121-140. 
Awang, Z. (2012). Structural equation modeling using AMOS graphic. Penerbit Universiti Teknologi MARA.

Ayodele, S. O., Oga, O. E., Bundot, Y. G., \& Ogbari, nd M. E. (2016). Role of power supply towards e-learning acceptance: VBSEM-AMOS. Proc. Int. Conf. Inf. Commun. Manage. (ICICM), 151155 .

Bazelais, P., Doleck, T., \& Lemay, D. J. (2018). Investigating the predictive power of TAM: A case study of CEGEP students' intentions to use online learning technologies. Educ. Inf. Technol, 23(1), 93-111.

Beldarrain, Y. (2006). Distance education trends: Integrating new technologies to foster student interaction and collaboration. Distance Education, 27(2), 139-153.

Calisir, F., Gumussoy, C. A., Bayraktaroglu, A. E., \& Karaali, D. (2014). Predicting the Intention to Use a Web-Based Learning System: Perceived Content Quality, Anxiety, Perceived System Quality, Image , and the Technology Acceptance Model, 24(5), 515-531.

Chang, C.-T., Hajiyev, J., \& Su, C. R. (2017). Examining the students' behavioral intention to use e-learning in Azerbaijan? The General Extended Technology Acceptance Model for E-learning approach. Computers and Education, 111, 128-143.

Chen, Y., Lin, Y., \& Lou, S. (2013). Examining factors affecting college students' intention to use web-based instruction systems: Towards an integrated model, 12(2), 111-121.

Cheng, W. L. (2019). Choosing between the theory of planned behavior (TPB) and the technology acceptance model (TAM). Educational Technology Research and Development, 67(1), 21-37.

Cheng, Y. M. (2011). Antecedents and consequences of e-learning acceptance. Information Systems Journal, 21(3), 269-299.

Chesbrough, H. (2020). Higher Education At The Covid-19 Crossroads. Retrieved May 20, 2020 from https://www.forbes.com/sites/henrychesbrough/2020/05/19/higher-education-at-the-covid-19crossroads/\#4f46dce7bee3

Chuttur, M. (2009). Overview of the Technology Acceptance Model: Origins, Developments and Future Directions. Sprouts: Working Papers on Information Systems, 9(37), 1-23.

Cole, C., Ray, K., \& Zanetis, J. (2009). Videoconferencing for K-12 classrooms: A program development guide. International Society for Technology in Education.

Coventry, L. (1995). Video Conferencing in Higher Education. In Institue for Computer Based Learning Heriot Watt University Edinburgh.

Credit Suisse. (2020). The growing demand for EdTech during coronavirus lockdown. Retrieved April 10, 2020 from https://www.credit-suisse.com/about-us-news/en/articles/news-and-expertise/educationtechnology-and-coronavirus-pandemic-202004.html

Dasgupta, S., Granger, M., \& Mcgarry, N. (2002). User acceptance of e-collaboration technology: An extension of the technology acceptance model. Group Decision and Negotiation, 11(2), 87-100.

Davis. (1989). Perceived Usefulness, Perceived Ease of Use, and User Acceptance of Information Technology. MIS Quarterly. 13 (3), 319-340.

Davis, F. D., Bagozzi, R. P., \& Warshaw, P. R. (1992). Extrinsic and Intrinsic Motivation to Use Computers in the Workplace 1. Journal of applied social psychology, 22(14), 1111-1132.

Debski, R. (1997). Support of creativity and collaboration in the language classroom: A new role for technology. Language Learning through Social Computing, 16, 41-65.

Deci, E. L., \& Ryan, R. M. (1985). Conceptualizations of intrinsic motivation and self-determination. In Intrinsic motivation and self-determination in human behavior. In Springer, Boston, MA.

Deshpande, Y., Bhattacharya, S., \& Yammiyavar, P. (2012). A behavioral approach to modeling Indian children's ability of adopting to e-learning environment. 4th International Conference on Intelligent Human Computer Interaction: Advancing Technology for Humanity, (IHCI), 2012 (pp. 1-7). IEEE. 
Dumpit, D. Z., \& Fernandez, C. J. (2017). Analysis of the use of social media in Higher Education Institutions (HEIs) using the Technology Acceptance Model. International Journal of Educational Technology in Higher Education, 14(1), 5.

El-Gayar, O., Moran, M., \& Hawkes, M. (2011). Students' acceptance of tablet PCs and implications for educational institutions. Journal of Educational Technology \& Society, 14(2), 58-70. Journal of Educational Technology \& Society, 14(2), 58-70.

Estriegana, R., Medina-Merodio, J. A., \& Barchino, R. (2019). Student acceptance of virtual laboratory and practical work: An extension of the technology acceptance model. Computers and Education, 135, $1-14$.

F. Hair, J., C. Black, W., J. Babin, B., \& E. Anderson, R. (2010). Multivariate data analysis (7th ed.). New Jersey, Pearson.

Fedorko, I., Bacik, R., \& Gavurova, B. (2018). Technology acceptance model in e-commerce segment. Management \& Marketing. Challenges for the Knowledge Society, 13(4), 1242-1256.

Fishbein, M., \& Ajzen, I. (1975). Strategies of Change: Active Participation. In Belief, attitude, intention, and behavior: An introduction to theory and research.

Fornell, C., \& Larcker, D. F. (1981). Evaluating structural equation models with unobservable variables and measurement error. Journal of Marketing Research, 18(1), 39-50.

Forza, C., \& Filippini, R. (1998). TQM impact on quality conformance and customer satisfaction: a causal model. International Journal of Production Economics, 55(1), 1-20.

Garrison, D. R., \& Kanuka, H. (2004). Blended learning: Uncovering its transformative potential in higher education. The Internet and Higher Education, 7(2), 95-105.

Gillies, D. (2008). Student perspectives on videoconferencing in teacher education at a distance. Distance Education, 29(1), 107-118.

Gorbalenya, A. E., Baker, S. C., Baric, R. S., Groot, R. J. De, Gulyaeva, A. A., Haagmans, B. L., Lauber, C., \& Leontovich, A. M. (2020). Severe acute respiratory syndrome-related coronavirus: The species and its viruses - a statement of the Coronavirus Study Group. Biorxiv (Cold Spring Harbor Laboratory).

Graham, C. R. (2006). Blended learning systems: Definition, current trends, and future directions. In Handbook of blended learning: Global perspectives, local designs. John Wiley \& Sons.

Granic, A., \& Marangunic, N. (2019). Technology acceptance model in educational context: A systematic literature review. IEEE Access, 28(2), 273-315.

Greenberg, A., \& Colbert, R. (2004). Navigating the sea of research on video conferencing-based distance education. Wainhouse Research, LLC.

Ha Anh. (2020). Nhiều trường dại học công nhận dạy học trực tuyến. Retrieved March 16, 2020 from https://thanhnien.vn/giao-duc/nhieu-truong-dai-hoc-cong-nhan-day-hoc-truc-tuyen-1196328. html

Hanif, A., Jamal, F. Q., \& Imran, M. (2018). Extending the technology acceptance model for use of e-learning systems by digital learners. IEEE Access, 6, (pp. 73395-73404). IEEE.

Haryanto, H., \& Kultsum, H. U. (2016). E-learning program adoption: Technology acceptance model approach. Proceeding of the International Conference on Teacher Training and Education, 2(1), 616622.

Gorbalenya, A. E., Baker, S. C., Baric, R. S., Groot, R. J. De, Gulyaeva, A. A., Haagmans, B. L., Lauber, C., \& Leontovich, A. M. (2020). Severe acute respiratory syndrome-related coronavirus: The species and its viruses - a statement of the Coronavirus Study Group. Biorxiv (Cold Spring Harbor Laboratory).

Graham, C. R. (2006). Blended learning systems: Definition, current trends, and future directions. In Handbook of blended learning: Global perspectives, local designs. John Wiley \& Sons. 
Granic, A., \& Marangunic, N. (2019). Technology acceptance model in educational context: A systematic literature review. IEEE Access, 28(2), 273-315.

Greenberg, A., \& Colbert, R. (2004). Navigating the sea of research on video conferencing-based distance education. Wainhouse Research, LLC.

Ha Anh. (2020). Nhiều trường dại học công nhận dạy học trực tuyến. Retrieved March 16, 2020 from https://thanhnien.vn/giao-duc/nhieu-truong-dai-hoc-cong-nhan-day-hoc-truc-tuyen-1196328. html

Hanif, A., Jamal, F. Q., \& Imran, M. (2018). Extending the technology acceptance model for use of e-learning systems by digital learners. IEEE Access, 6, (pp. 73395-73404). IEEE.

Haryanto, H., \& Kultsum, H. U. (2016). E-learning program adoption: Technology acceptance model approach. Proceeding of the International Conference on Teacher Training and Education, 2(1), 616622.

Lee, W. H., Lin, C. W., \& Shih, K. H. (2018). A technology acceptance model for the perception of restaurant service robots for trust, interactivity, and output quality. International Journal of Mobile Communications, 16(4), 361-376.

Lee, Y. C. (2006). An empirical investigation into factors influencing the adoption of an e-learning system. Online Information Review, 30(5), 517-541.

Legris, P., Ingham, J., \& Collerette, P. (2003). Why do people use information technology ? A critical review of the technology acceptance model. 40, 191-204.

Lemay, D. J., Morin, M. M., Bazelais, P., \& Doleck, T. (2018). Modeling Students' Perceptions of SimulationBased Learning Using the Technology Acceptance Model. Clinical Simulation in Nursing, 20, $28-37$.

Leonard-Barton, D., \& Deschamps, I. (1998). Managerial Influence in the Implementation of New Technology Managerial Influence In The Implementation Of New Technolog. Management Science, 34(10), 1252-1265.

Levy, M. (1998). Two conceptions of learning and their implications for CALL at the tertiary level. ReCALL, 10(1), 86-94.

Li, C., \& Lalani, F. (2020). The COVID-19 pandemic has changed education forever. This is how. Retrieved April 29, 2020 from https://www.weforum.org/agenda/2020/04/coronavirus-education-globalcovid19-online-digital-learning/

Li, L. (2010). A critical review of technology acceptance literature. Referred Research Paper, 4.

Liao, H. L., \& Lu, H. P. (2008). The role of experience and innovation characteristics in the adoption and continued use of e-learning websites. Computers and Education, 51(4), 1405-1416.

Mader, C., \& Ming, K. (2015). Videoconferencing: A New Opportunity to Facilitate Learning. The Clearing House: A Journal of Educational Strategies, Issues and Ideas, 88(4), 109-116.

Mahmodi, M. (2017). The Analysis of the Factors Affecting the Acceptance of E-learning in Higher Education. Interdiscipl. J. Virtual Learn. Med. Sci, 8(1).

Martins, L. L., \& Kellermanns, F. W. (2004). A Model of Business School Students' Acceptance of a WebBased Course Management System. Academy of Management Learning \& Education, 3(1), 7-26.

Masrom, M. (2007). Technology acceptance model and E-learning. Technology, 21(24), 81.

Mathieson, K. (1991). Predicting user intentions: Comparing the technology acceptance model with the theory of planned behavior. Information Systems Research, 2(3), 173-191.

Moody, R. A., \& Wieland, R. L. (2010). Using Videoconferencing to Establish and Maintain a Social Presence in Online Learning Environments. Educational Considerations, 37(2), 18-21.

Moon, J. W., \& Kim, Y. G. (2001). Extending the TAM for a World-Wide-Web context. Information and Management, 38(4), 217-230. 
Moore, J. L., Dickson-Deane, C., \& Galyen, K. (2011). E-Learning, online learning, and distance learning environments: Are they the same? Internet and Higher Education, 14(2), 129-135.

Mou, J., Shin, D. H., \& Cohen, J. (2017). Understanding trust and perceived usefulness in the consumer acceptance of an e-service: a longitudinal investigation. Behaviour and Information Technology, 36(2), 125-139.

Nassuora, A. (2013). Students Acceptance of Mobile Learning for Higher Education in Saudi Arabia. International Journal of Learning Management Systems, 1(1), 1-9.

Nesi, H. (2004). Language learning online: towards best practice. System, 32(3), 466-468.

Offir, B., \& Lev, Y. (1999). Teacher-learner interaction in the process of operating $\mathrm{dl}$ (distance learning) systems. Education Media International, 36(2), 132-136.

Online Newspaper of The Goverment Vietnam. (2020). Bộ GD ÚDDT hợp tác với UNICEF úng phó với COVID-19. Retrieved April 18, 2020 from http://baochinhphu.vn/Hoat-dong-Bo-nganh/BoGDDT-hop-tac-voi-UNICEF-ung-pho-voi-COVID19/393433.vgp

Park, N., Rhoads, M., Hou, J., \& Lee, K. M. (2014). Understanding the acceptance of teleconferencing systems among employees: An extension of the technology acceptance model. Computers in Human Behavior, 39, 118-127.

Park, N., Roman, R., Lee, S., \& Chung, J. E. (2009). User acceptance of a digital library system in developing countries: An application of the Technology Acceptance Model. International Journal of Information Management, 29(3), 196-209.

Park, S. Y. (2009). An analysis of the technology acceptance model in understanding University students' behavioral intention to use e-Learning. Journal of Educational Technology \& Society, 12(3), 150162.

Parsad, B., \& Lewis, L. (2008). Distance Education at Degree-Granting Postsecondary Distance Education at Degree-Granting Postsecondary Institutions : 2006-2007. In World Wide Web Internet And Web Information Systems. Washington, DC: National Center for Education Statistics, Institute of Education Sciences, US Department of Education.

Rauniar, R., Rawski, G., Yang, J., \& Johnson, B. (2014). Technology acceptance model (TAM) and social media usage: An empirical study on Facebook. Journal of Enterprise Information Management, 27(1), 6-30.

Rejón-Guardia, F., Sánchez-Fernández, J., \& Muñoz-Leiva, F. (2013). The acceptance of microblogging in the learning process: The $\mu$ BAM model. Journal of Technology and Science Education, 3(1), 31-47.

Revythi, A., \& Tselios, N. (2019). Extension of technology acceptance model by using system usability scale to assess behavioral intention to use e-learning. Education and Information Technologies, 24(4), 2341-2355.

Salloum, S. A., Qasim Mohammad Alhamad, A., Al-Emran, M., Abdel Monem, A., \& Shaalan, K. (2019). Exploring students' acceptance of e-learning through the development of a comprehensive technology acceptance model. IEEE Access, 7, 128445-128462. IEEE.

Salmon, G. (2000). Computer Mediated Conferencing for Management Learning at the Open University. Management Learning, 31(4), 491-502.

Sanchez-Franco, M. J., Martinez-Lopez, F. J., \& MartinVelicia, F. A. (2009). Exploring the impact of individualism and uncertainty avoidance in web-based electronic learning: An empirical analysis in European higher education. Computers \& Education, 52(3), 588-598.

Scherer, R., Siddiq, F., \& Tondeur, J. (2019). The technology acceptance model (TAM): A meta-analytic structural equation modeling approach to explaining teachers' adoption of digital technology in education. Computers and Education, 128, 13-35.

Sharma, S. K. (2019). Integrating cognitive antecedents into TAM to explain mobile banking behavioral intention: A SEM-neural network modeling. Information Systems Frontiers, 21(4), 815-827. 
Shen, J., \& Eder, L. B. (2009). Intentions to Use Virtual Worlds for Education. Journal of Information Systems Education, 20(2), 225-234.

Singh, P., Keswani, S., Singh, S., \& Sharma, S. (2018). A Study of Adoption Behavior for Online Shopping: An Extension of Tam Model. IJASSH.

Stoel, L., \& Lee, K. H. (2003). Modeling the effect of experience on student acceptance of Web-based courseware. Internet Research, 13(5), 364-374.

Sun, H., \& Zhang, P. (2008). An exploration of affect factors and their role in user technology acceptance: Mediation and causality. Journal of the American Society for Information Science and Technology, 59(8), 1252-1263.

Sun, J., Umeng, He, W. T., Wang, L., Lai, A., Ji, X., Zhai, X., Li, G., Suchard, M. A., Tian, J., Zhou, J., Veit, M., \& Su, S. (2020). COVID-19: Epidemiology, Evolution, and Cross-Disciplinary Perspectives. Trends in Molecular Medicine, 26(5), 483-495.

Tan, G. W. H., Ooi, K. B., Sim, J. J., \& Phusavat, K. (2012). Determinants of mobile learning adoption: An empirical analysis. Journal of Computer Information Systems, 52(3), 82-91.

Tarhini, A., Hone, K., Liu, X., \& Tarhini, T. (2017). Examining the moderating effect of individual-level cultural values on users' acceptance of E-learning in developing countries: a structural equation modeling of an extended technology acceptance model. Interactive Learning Environments, 25(3), $306-328$.

Taylor, S., \& Todd, P. A. (1995). Understanding information technology usage: A test of competing models. Information Systems Research, 6(2), 144-176.

Teng, K. E. (2014). An analysis of ODL student perception and adoption behavior using the technology acceptance model. International Review of Research in Open and Distance Learning, 15(6), 275288.

Teo, T. S. H., Srivastava, S. C., \& Jiang, L. (2008). Trust and electronic government success: An empirical study. Journal of Management Information Systems, 25(3), 99-132.

Teo, T., Ursavas, O. F., \& Bahcekapili, E. (2011). Efficiency of the technology acceptance model to explain pre-service teachers' intention to use technology. Campus-Wide Information Systems, 28(2), 93101.

Tran, H. (2020). Nghỉ học dai ngay: Trường dại học dễ "chuyển hướng" hơn. Retrieved February 08, 2020 from https://tuoitre.vn/nghi-hoc-dai-ngay-truong-dai-hoc-de-chuyen-huonghon-20200207232817494.htm

UNESCO. (2020a). Distance learning solutions. Retrieved March 16, 2020 from https://En.Unesco.Org/. https://en.unesco.org/covid19/educationresponse/solutions

UNESCO. (2020b). Education Response to COVID-19 in the Caribbean. Retrieved March 01, 2020 from https://en.unesco.org/covid19/educationresponse/solutions

Vandenberg, R. J. (2006). Statistical and Methodological Myths and Urban Legends Where, Pray Tell , Did They Get This Idea ? Organizational Research Methods, 9(2), 194-201.

Venkatesh, V., Morris, M. G., Davis, G. B., \& Davis, F. D. (2003). User acceptance of information technology: Toward a unified view. , 425-478. MIS Quarterly, 425-478.

Venkatesh, V. (2000). Determinants of perceived ease of use: Integrating perceived behavioral control, computer anxiety and enjoyment into the technology acceptance model. Information Systems Research, 11(1), 3-11.

Venkatesh, Viswanath, \& Bala, H. (2008). Technology acceptance model 3 and a research agenda on interventions. Decision Sciences, 39(2), 273-315.

Venkatesh, Viswanath, \& Davis, F. D. (2000). Theoretical extension of the Technology Acceptance Model: Four longitudinal field studies. Management Science, 46(2), 186-204. 
Vidanagama, D. U. (2016). Acceptance of E-Learning among Undergraduates of Computing Degrees in Sri Lanka. International Journal of Modern Education and Computer Science, 4, 25-32.

Vietnam Ministry of Education and Training. (2020). Official Letter No. 795 / BGDĐT-GDĐH dated 13/3/2020 about the implementation of distance learning in response to Covid-19. https://moet.gov. $\mathrm{vn} / \mathrm{van}$-ban/vbdh/Pages/chi-tiet-van-ban.aspx?ItemID=2668

Vietnam Ministry of Health. (2020). Official Dispatch Number 358/BYT-DP on 26 Jan 2020 about Cooperation in Communication, Surveillance, and Investigation of an Outbreak of Acute Respiratory Infection Caused by $n$ CoV.

Vietnam National University Media. (2020). Dạy va học trụ̣c tuyến thời Covid-19 tại ULIS. Retrieved March 18, 2020 from https://www.vnu.edu.vn/ttsk/?C151/N25573/Day-va-hoc-truc-tuyenthoi-Covid-19-tai-ULIS.htm

Vietnamese Government. (2020). Decision No. 173/QĐ-TTg upon the Announcement of Acute Respiratory Infection Caused by a New Coronavirus.

Vygotsky, L. S. (1978). Mind and Society: The Development of Higher Psychological Processes. Harvard University Press.

Warschauer, M. (1997). Computer-Mediated Collaborative Learning: Theory and Practice. The modern language journal, 81(4), 470-481.

Webster, J., Heian, J. B., \& Michelman, J. E. (1990). Computer Training and Computer Anxiety in the Educational Process : an Experimental Analysis in the Educational Process. International Conference on Information Systems 34, 171-182.

Webster, J., Martocchio, J. J., \& Webster, B. J. (1992). Microcomputer Playfulness : Development of a Measure With Workplace Implications. 16(2), 201-226.

Weston, S., \& Frieman, M. B. (2020). COVID-19: Knowns, Unknowns, and Questions. MSphere, 5(2).

Wilkerson, L. (2004). The History of Video Conferencing - Moving Ahead at the Speed of Video. Retrieved May 11, 2020 from http://fotogold.pl/the-history-of-video-conferencing-moving-ahead-at-the-speedof-video/

Willis, J. (1996). A flexible framework for task-based learning An overview of a task-based framework for language teaching. Oxford, 52-62.

Wong, G. K. W. (2016). The behavioral intentions of Hong Kong primary teachers in adopting educational technology. Educational Technology Research and Development, 64(2), 313-338.

World Bank. (2020). Remote Learning, EdTech \& COVID-19. Retrieved May 21, 2020 from https://www. worldbank.org/en/topic/edutech/brief/edtech-covid-19

World Health Organization. (2020). Rolling updates on coronavirus disease (COVID-19). Retrieved January 30, 2020 from https://www. Who.Int/Emergencies/Diseases/Novel-Coronavirus-2019/Events-asThey-Happen.

Wu, P. F. (2009). Opening the black boxes of TAM: towards a mixed methods approach. ICIS 2009 Proceedings, 1-10. Associate for Information Systems.

Zare, H., \& Yazdanparast, S. (2013). The causal model of effective factors on intention to use of information technology among payamnoor and traditional universities student. Life Science Journal, 10(2), $46-50$. 